\title{
Context-dependent effects of suspension feeding on intertidal ecosystem functioning
}

\author{
F. Rossi ${ }^{1, *}$, B. Gribsholt ${ }^{2}$, J. J. Middelburg ${ }^{1}$, C. Heip ${ }^{1}$ \\ ${ }^{1}$ Netherlands Institute of Ecology (NIOO-KNAW), Centre for Estuarine and Marine Ecology, PO Box 140, 4400 AC Yerseke, \\ The Netherlands \\ ${ }^{2}$ Marine Biological Laboratory, University of Copenhagen, Strandpromenaden 5, 3000 Helsingør, Denmark
}

\begin{abstract}
Species loss or gain can change ecosystem functions according to the ecological context (e.g. assemblage composition, habitat heterogeneity and disturbance regime). We document how the suspension-feeder cockle Cerastoderma edule (L.) affects some properties of intertidal sediments during macrofauna recovery after deliberately induced anoxia. Forty adult cockles were transplanted to each of 12 plots $(25 \times 25 \mathrm{~cm})$ in 3 physically homogeneous patches $(4 \times 4 \mathrm{~m})$. Two patches had recolonised for 4 or 7 mo (DJ and DM, respectively) and had a very similar number of species (DJ: $4.5 \pm 0.3$ and DM: $5 \pm 0.0$ ). The other patch $(C)$ was natural sediment with a relatively high species diversity $(6.5 \pm 0.6)$. Species composition was different among the 3 patches (DJ $<\mathrm{DM}<\mathrm{C}$ ) and indicated an increasing number of individuals and functional groups in accordance with the duration of the recovery period ( $\mathrm{DJ}<\mathrm{DM}<\mathrm{C}$ ). Changes in abundance of the resident macrofauna, in total benthic mineralization rates (oxygen uptake and carbon dioxide release) and in the exchange of inorganic nitrogen at the sediment-water interface were compared between transplanted and undisturbed plots. The functional response of the sediment ecosystem to the gain of $C$. edule varied among the patches. Following $C$. edule addition, ammonium release increased 3 to 4 times in the sediment which had been recolonising for 7 mo (DM), while uptake of nitrate decreased at similar levels in the other 2 patches (DJ and C). Effects were related to variations in the densities of 2 species, namely new recruits of the surface deposit-feeder Macoma balthica $(\leq 5 \mathrm{~mm})$ and the surface-detritivore and bioirrigator Hediste diversicolor. Cockles caused a decrease in the densities of $M$. balthica ( $\leq 5 \mathrm{~mm})$ and an increase in those of $H$. diversicolor, mainly in DM. Cockles also modified how densities of these species and of Heteromastus filiformis correlated to sediment-water exchanges of ammonium and oxygen. C. edule also enhanced oxygen uptake at all sites, mainly due to its specific respiration rate. Variability in the functional response among patches of habitat (e.g. context-dependence) resulted as a consequence of biotic interactions between the cockles and the resident infauna.
\end{abstract}

KEY WORDS: Context-dependence - Biodiversity - Benthic respiration - Nitrogen cycling · Macrofauna $\cdot$ Suspension feeding $\cdot$ Mudflats

Resale or republication not permitted without written consent of the publisher

\section{INTRODUCTION}

Concerns about human-induced biodiversity losses have stimulated interest in understanding the relationships that link biodiversity to ecological properties as well as to the 'goods and services' that ecosystems can provide to mankind (Loreau et al. 2002, Hooper et al. 2005). In addition to the ethical and philosophical value that the preservation of biodiversity should have, knowledge of the relationships between biodiversity and ecosystem functioning is of great relevance for the conservation and management of natural resources (Costanza et al. 1997, Heip 1998, Chapin et al. 2000). Naeem et al. (2002) distinguished 3 classes of models to identify the effect of species diversity on ecosystem functioning, the well-known 'redundant', 'singular' and 'context-dependence' effects. Context-dependency implies that the hypothesized trajectory of the biodi- 
versity-ecosystem functioning relationship is complex and non-monotonic. This does not mean that the response of an ecosystem to changes in biodiversity cannot be predicted. Rather, it suggests that species diversity can govern ecosystem functions, but the magnitude and the direction of these effects depend on the conditions (e.g. species composition, habitat characteristics and disturbance regime) under which the local extinction or addition occurs (Cardinale et al. 2000, Cardinale \& Palmer 2002, Naeem et al. 2002). Researchers have often explained inconsistent patterns as being related to context-dependency. Until now, however, there has been little effort to determine whether inconsistent patterns can, instead, be predicted from increasing information on the range of conditions under which the relationship is positive and monotonic (Cardinale et al. 2000, Wardle \& Zackrisson 2005).

Spatial and temporal heterogeneity and the dimensions of the habitat as well as the disturbance regime can modify the link between species diversity and biogeochemical properties in streams, marine sediments and soils because they change the behavior and relative dominance of the species in the assemblages (Cardinale et al. 2000, Cardinale \& Palmer 2002, Biles et al. 2003, Wardle \& Zackrisson 2005). In streams and marine sediments, for example, infauna changes due to disturbance increase nutrient cycling directly when these changes increase the complementarity properties of the infauna (e.g. facilitation or resource partition), or indirectly, when they modify interaction strength between infauna and other functionally relevant taxa in the community (Cardinale \& Palmer 2002, Biles et al. 2003). Furthermore, even under homogeneous conditions of physical disturbance, the composition of assemblages changes the effects of functionally relevant taxa on ecosystem properties. This is the case, for example, for zooplanktivorous and benthic fish, whose effects on food resources depend upon the presence of other trophically similar species (Nowlin \& Drenner 2000, Bruno \& O'Connor 2005).

Early biodiversity experiments have randomly assembled a very limited number of species for a relatively short time in mesocosms, deliberately limiting the complexity of indirect and direct interactions, while focusing on the effects of selected species alone and in artificial combinations (e.g. Naeem et al. 1994, Petchey 2003). These synthetic assemblage experiments have contributed significantly to the biodiversity-functioning theories, but they cannot explain how the context can modify the biodiversity-functioning link because species kept together artificially under laboratory conditions do not interact among each other and with the environment as if they coexisted under natural conditions. More recently, researchers have used a combination of experiments in the mesocosm and in the field with synthetic assemblages or with natural communities, from which a randon selection of species was removed (Tilman et al. 1997, Stachowicz et al. 1999, Emmerson et al. 2001, Diaz et al. 2003, Schmid \& Hector 2004, Wardle \& Zackrisson 2005). However, we have to consider that species loss and community shifts are not random processes, but rather that they reflect the sensitivity of species to disturbance and to the type of disturbance affecting the ecosystem (Solan et al. 2004). Research should thus evaluate simultaneously changes in diversity and functions under the most natural conditions possible in order to include effects caused by species interactions and environmental changes.

It is well known that marine sediments play a major role in coastal biogeochemical cycles and that infauna can alter the pathways and intensity of organic matter degradation and sediment-water exchanges of nutrients (Herman et al. 1999). Correlative studies and simplistic synthetic assemblage experiments have highlighted the potential for biodiversity-functional relationships between infaunal diversity and sediment biogeochemical processes (Naeem et al. 1994, Emmerson et al. 2001, Waldbusser \& Marinelli 2006). Under natural conditions, however, the effects of species can be related to both species-functional traits and ecological interactions at the same time, especially for properties related to the biogeochemistry, where functional characteristics of individual animals, their relative abundances and behavior can interact at the community level (Waldbusser \& Marinelli 2006). The work done in the field has documented not only the importance of idiosyncratic effects related to the functional traits of particular species (e.g. Emmerson et al. 2001, Thrush et al. 2006), but also the lack of diversityrelated change in some ecosystem processes (Bolam et al. 2002). Such complexity calls for information on the circumstances under which we can get a positive and consistent response of sediment biogeochemistry to changes in diversity and species identity.

Local loss or gain of suspension-feeders can have important consequences for ecosystem functions which can be difficult to predict using simplistic experiments because suspension-feeders can modify ecosystem functions either directly or through their effects on other species' density and behavior. Suspensionfeeders accelerate biodeposition and the removal of organic carbon from the water column, thereby altering directly the exchange of carbon and nutrients at the sediment-water interface. They are also habitat modifiers, with a range of effects on the density and behavior of the surrounding macrofauna (Wilson 1990, Alpine \& Cloern 1992, Kamermans 1994, Herman et al. 1999, Thrush et al. 2006). 
In the present study, we show how the gain of the suspension-feeder cockle Cerastoderma edule (L.) modifies the biogeochemistry of physically homogeneous patches of intertidal sediments where macrofauna was at different stages of recovery from severe anoxia or had been left undisturbed. We predict that the deliberate addition of suspension-feeders will change the sediment biogeochemistry and that the direction of effects will be consistent for recovering and undisturbed sediments. Furthermore, when indirect effects of cockles on other species densities are prevalent, the deliberate addition of cockles will modify not only species composition and abundance but also the relationships between the biogeochemistry and densities of resident species.

\section{MATERIALS AND METHODS}

Experimental setup. The experiment was done in an intertidal mudflat of the Westerschelde estuary (Paulina Polder, The Netherlands) at a $50 \times 50 \mathrm{~m}$ location $\left(51^{\circ} 21^{\prime} 23^{\prime \prime} \mathrm{N}, 3^{\circ} 42^{\prime} 49^{\prime \prime} \mathrm{E}\right)$. The Paulina Polder mudflat covers an area of approximately $1.0 \mathrm{~km}^{2}$ and has a mean tidal range of $3.9 \mathrm{~m}$ with a semidiurnal regime. The sediment is in general very muddy with an average fine content (defined as $\%<63 \mu \mathrm{m}$ ) of $50 \%$.

Two relatively large patches $(4 \times 4 \mathrm{~m}), 10 \mathrm{~m}$ apart were covered with black plastic sheets and left to defaunate for 2 mo in January and May 2005. Then, on 29 March and 6 July, the plastic sheets were removed and the sediment was recolonised by surrounding taxa. These created patches at 2 different stages of recovery, with differential species composition (e.g. number of species, species identity and density). The patches will be referred to as DJ (defaunated until 6 July) and DM (defaunated until 29 March). A third patch was designated at the beginning of the defaunation as unmanipulated sediment (referred to hereafter as C).

In the same area, other similar patches were defaunated in order to study recolonisation patterns of microbes and macrofauna, sediment characteristics and carbon cycling during recolonisation. Two mo after the end of defaunation, the microbial community had fully recolonised and other environmental variables such as grain size or total organic matter did not show any significant differences between the defaunated and the control patches (C. van Coelen \& F. Montserrat unpubl. data). In September, average biomass of heterotrophic bacteria (ng g ${ }^{-1} \mathrm{C}_{i}$ mean $\pm \mathrm{SE}, \mathrm{n}=12$ ) was $190.6 \pm 3.4$, $200.5 \pm 3.7$ and $198.6 \pm 27.7$ in DJ, DM and $C$, respectively. Microalgal biomasses $\left(\mathrm{ng} \mathrm{g}^{-1} \mathrm{C}_{\text {; }}\right.$ mean $\pm \mathrm{SE}, \mathrm{n}=$ 12) were $403.1 \pm 35.3,453.1 \pm 63.0$ and $369.4 \pm 13.1$ in DJ, DM and $\mathrm{C}$, respectively (F. Rossi unpubl. data). Microbial biomass was quantified from phosphor-lipid derived fatty acids (Boschker \& Middelburg 2002). Mud content (defined as \% <63 $\mu \mathrm{m}$ ) ranged between $36 \pm 1$ and $47 \pm 4$ (mean $\pm \mathrm{SE}, \mathrm{n}=5)$ in 3 additional patches of natural sediment (C) and between $43 \pm 3$ and $50 \pm 3$ in the DM sediment.

The macrofauna showed differences and there were still no adult suspension-feeders in the recovering patches (F. Rossi unpubl. data, present study). Suspension-feeders, including the cockle Cerastoderma edule, were common in the natural sediment. Their distribution was patchy over small scales. In November, density of adult cockle ( $>13 \mathrm{~mm}$; mean $\pm \mathrm{SE}, \mathrm{n}=3$ ) ranged between $0 \pm 0$ and $5 \pm 1$ ind. per $78 \mathrm{~cm}^{2}$ when cores were collected randomly at a scale of $<4 \mathrm{~m}$ (Rossi et al. 2007).

On 7 November 2005 adult cockles Cerastoderma edule (mean shell length: $20 \mathrm{~mm}$; biomass of $0.9 \mathrm{mg}$ dry weight $[\mathrm{DW}]$ ind. $^{-1}$ ) were transplanted within the 3 patches. Within each patch, eight $25 \times 25 \mathrm{~cm}$ plots were randomly selected and 40 cockles (this number of individuals correspond to a density of 640 ind. $\mathrm{m}^{-2}$, which is the highest density measured in the study area) were transplanted in 4 of them (treatment ' + '). The other 4 plots were left undisturbed (treatment ' - '). In this study, resident cockles were $3 \pm 1$ ind. core $^{-1}$ (mean $\pm \mathrm{SE}, \mathrm{n}=4$ ), with a biomass of $0.1 \pm 0.1 \mathrm{mg}$ core $^{-1}$. Only 1 of the 4 plots without added cockles had an abundance ( 6 ind.) and biomass $(0.38 \mathrm{mg}$ ) comparable to the number of cockles transplanted (see also Fig. 2b). Statistical analyses were done including and excluding this plot. Results are reported when differences were found (see 'Results' section).

The cockles were randomly collected from the surroundings during low tide, measured, labelled with nail polish and transplanted the same day. The cockles were homogeneously distributed on the sediment surface of each plot using a grid, taking care not to disrupt the sediment surface while handling the animals. The cockles rapidly buried themselves with the incoming tide. No artefact control was done to measure whether the handling of cockles would have affected the results because there was no visual disturbance of the sediment surface during the transplanting.

Sampling was done 2 wk after transplantation (21 November 2005) and no dead labelled cockles were collected. The transplanted cockles were recovered at similar densities (1-way analyses of variance [ANOVA] : $F_{2,9}=1.21, \mathrm{p}=0.34 ;$ with $6.0 \pm 0.7 ; 6.7 \pm 0.3$; $5.5 \pm 0.6$ ind. core $^{-1}$, in $\mathrm{C}+, \mathrm{DM}+$ and $\mathrm{DJ}+$, respectively).

Field sampling and analyses. For flux incubations, and subsequent macrofauna determination, one large Plexiglas core $(11 \mathrm{~cm}$ internal diameter, i.d.) was collected to a depth of $30 \mathrm{~cm}$ at each of the 8 plots in each patch. Two other cores $(5 \mathrm{~cm}$ i.d.) were taken to a depth of $10 \mathrm{~cm}$ for porewater extraction. Cores were 
immediately sealed with rubber stoppers, brought to a climate-controlled room within $2 \mathrm{~h}$, and kept in the dark at in situ temperature $\left(10^{\circ} \mathrm{C}\right)$ before further handling.

Flux incubation was for $12 \mathrm{~h}$ in the dark at in situ temperature. Prior to incubations, cores were inundated with well-oxygenated Westerschelde water collected the same day $\left(\left[\mathrm{NH}_{4}{ }^{+}\right]=20 \mu \mathrm{mol} \mathrm{l} \mathrm{l}^{-1}\right.$, $\left[\mathrm{NO}_{3}{ }^{-}\right]=$ $110 \mu \mathrm{mol} \mathrm{l}^{-1}$, salinity $=22$ ) and left to acclimatise in the dark for 6 to $8 \mathrm{~h}$. The overlying water column (25 to $30 \mathrm{~cm}$ ) was continuously stirred with a magnetic stirrer, maintaining a continuous water circulation at a rate well below the resuspension limit, and dissolved $\mathrm{O}_{2}$ never decreased below $65 \%$ air-saturation.

Exchange rates of $\mathrm{O}_{2}$, total $\mathrm{CO}_{2}\left(\mathrm{TCO}_{2}=\mathrm{H}_{2} \mathrm{CO}_{3}+\right.$ $\mathrm{HCO}_{3}^{-}+\mathrm{CO}_{3}{ }^{2-}$ ) and DIN (dissolved inorganic nitrogen; $\mathrm{NO}_{2}^{-}+\mathrm{NO}_{3}^{-}$and $\mathrm{NH}_{4}{ }^{+}$) across the sedimentwater interface were determined from the concentration difference between initial and final samples, assuming constant solute exchange with time. $\mathrm{O}_{2}$ was analyzed by the standard Winkler technique and $\mathrm{TCO}_{2}$ was determined by the flow injection/diffusion cell technique of Hall \& Aller (1992). Samples for DIN determinations were immediately filtered (Millipore $45 \mu \mathrm{m})$ and stored frozen for later analysis using automated colorimetric techniques.

At the end of the incubation, the sediment in each core was sieved (0.5 mm mesh) for macrofauna analyses. Samples were sorted under a dissecting microscope, and species identified, counted and dried at $60^{\circ} \mathrm{C}$ for $48 \mathrm{~h}$ to determine biomass. We did not observe any loss of macrofauna related to the biogeochemical procedure, except Hydrobia ulvae that crawled on the walls of the cores. This effect was, however, homogeneous over all cores. Introduced (marked) cockles were measured separately. The shell length of the bivalves was measured to distinguish between adult and juvenile individuals, and specimens of the clam Macoma balthica and the cockle Cerastoderma edule were subdivided into size-classes. The cockles were separated into 2 size-classes (Class I: $\leq 13 \mathrm{~mm}$; and Class II: $>13 \mathrm{~mm}$ ) based on the bi-modal size-class distribution in the area (F. Rossi unpubl. data). Initially, M. balthica was separated into 3 size-classes (Rossi et al. 2004): Class I: $\leq 5 \mathrm{~mm}$ (new recruits); Class II: between 5 and $10 \mathrm{~mm}$ (juveniles); and Class III: >10 mm (adults). However, juveniles and adults ( $>5 \mathrm{~mm}$ ) occurred in the undisturbed patch only and their abundance is considered together.

The cores for porewater extraction ( $5 \mathrm{~cm}$ i.d.) were sectioned into $0-1,1-2,2-4$ and $4-6 \mathrm{~cm}$ depth intervals, and the 2 cores from each plot were pooled to reach the amount of water needed for the analyses. Pore water was extracted by centrifugation $(1344 \times g$, $15 \mathrm{~min}$ ) and the supernatant filtered (Millipore $45 \mu \mathrm{m}$ ).
Samples for $\mathrm{TCO}_{2}$ were fixed with $\mathrm{HgCl}_{2}$ (saturated solution) and analyzed within $3 \mathrm{~d}$ as described above. Samples for DIN analysis were stored at $4^{\circ} \mathrm{C}$ and analyzed as described above within $24 \mathrm{~h}$.

Statistical analyses. A 2-way ANOVA was used for detecting changes in resident macrofauna and biogeochemistry due to the addition of the cockles. Specifically, we tested for differences in the total density, number of species (diversity), biomass, and in the abundance of the dominant species as identified using the INDVAL program (Dufrene \& Legendre 1997). Bivalves were analyzed separately for each size-class. The biomass of the worm Hediste diversicolor was analyzed because the species showed a large range of body size ( 0.001 to $0.04 \mathrm{mg}$ ind. ${ }^{-1}$ ). We also tested for differences in the exchange of $\mathrm{O}_{2}, \mathrm{CO}_{2}$ and DIN between the sediment and the overlying water, and in the $\mathrm{NH}_{4}{ }^{+}, \mathrm{NO}_{3}{ }^{-}$ and $\mathrm{CO}_{2}$ concentrations in the pore water.

Cockle addition (2 levels: ' + ' and '-') was treated as a fixed factor and Patch (3 levels: DJ, DM and C) as random and crossed to cockle addition. Patches at the same recolonisation stage were not replicated because of field constraints. Plots were interspersed within patches. This lack of replication biases estimates of the error term (Hurlbert 1984). In September, 4 replicate cores of sediment for macrofauna assemblages were sampled in 2 replicate patches of each recovery stage (DJ, DM and C) 3 times a week. At each time, analyses showed more variability among replicate cores than patches. In other words, the test for differences among patches over residual variability was never significant (PERMANOVA at time 3: pseudo- $F_{3,18}=0.8, \mathrm{p}=0.6$ ) (F. Rossi unpubl. data). We, therefore, used inferential statistics but we recognize that conclusions should be limited to these patches.

Permutational multivariate analyses of variance (PERMANOVA, Anderson 2001) based on Bray-Curtis dissimilarities on square-root transformed data were used to estimate variation in the multivariate assemblages. The analyses tested the same hypotheses described for univariate ANOVA but in a multivariate context. Each term in the analyses was tested using 4999 random permutations of the appropriate units. The analyses were done using the computer programs DISTLM.exe and PERMANOVA.exe (Anderson 2001).

Multivariate patterns were visualised by non-metric multi-dimensional scaling (nMDS) ordinations of each plot on the basis of a Bray-Curtis dissimilarity matrix on square-root transformed data using PRIMER 6 software (Clarke \& Gorley 2001). Species responsible for the multivariate patterns were identified with INDVAL routine (Dufrene \& Legendre 1997).

The product-moment correlation coefficient $r$ (estimate of the parameter $\rho$ ) was used to find correlative patterns of density or biomass of the resident taxa with 
the biogeochemistry. For all the variables the $r$ values were calculated separately for the plots amended with cockles (' + ' treatment) and those left undisturbed ('-' treatment). The correlations were evaluated only when the species were present in a significant proportion of the plots $(75 \%)$.

Eventually, when there were significant differences in the fluxes due to the addition of cockles, we quantified the specific effect $(E)$ of a cockle at each patch, $E(P)$, using:

$$
E(P)=\left\{\left[E\left(P_{\mathrm{t}}\right)\right]-\left[E\left(P_{\mathrm{u}}\right)\right]\right\} /(a)
$$

where $\left[E\left(P_{\mathrm{t}}\right)\right]$ is the mean $(\mathrm{n}=4)$ flux in the transplanted plots and $\left[E\left(P_{\mathrm{u}}\right)\right]$ is the mean $(\mathrm{n}=4)$ flux in the undisturbed plots. The differences are, then, divided by the average abundance of the cockles in the transplanted plots (a). We used abundance rather than biomass because cockles added had the same shell length and there were no differences in biomass. Furthermore, Waldbusser et al. (2004) considered abundance to have greater effects on sediment biogeochemistry. These estimates are intended to include both cockle direct effects (e.g. respiration) and stimulation of microbial processes in the sediment.

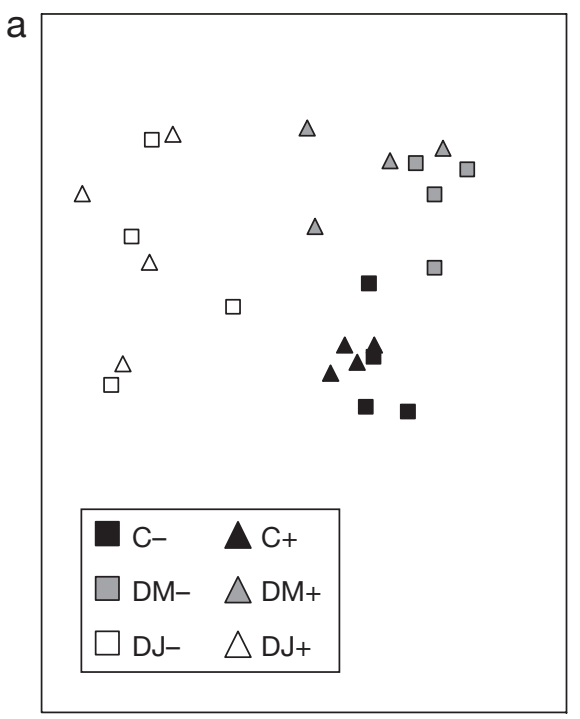

\section{RESULTS}

\section{Macrofauna species composition}

The 3 patches differed significantly in species composition (PERMANOVA, pseudo- $F_{2,18}=13.52, \mathrm{p}<$ 0.001 and 9.50, p < 0.001 for abundance and biomass data, respectively), and the ordination plots clearly illustrated these differences (Fig. 1a, shown for abundance only). There were more species with large biomasses in natural than recolonising sediment $\left(F_{2,18}=\right.$ $17.2, \mathrm{p}<0.001$ and $F_{2,18}=8.4, \mathrm{p}<0.001$, respectively) and the lowest abundance was in DJ $\left(F_{2,18}=55.0, \mathrm{p}<\right.$ 0.001; Fig. 1b). The addition of cockles did not significantly change biomass, number of species (diversity) and density (Fig. 1b).

We found a total of 12 species in our cores, including the unmarked cockle Cerastoderma edule. Six species dominated the assemblages and differentiated among patches (INDVAL test at $\mathrm{p}=0.05$; Fig. 2). Following cockle addition, newly recruited Macoma balthica decreased in DM, where they were initially the most abundant $\left(F_{2,18}=6.5, \mathrm{p}=0.01\right.$, Fig. $\left.2 \mathrm{a}\right)$ and abundance of Hediste diversicolor increased in all patches, mainly in $\mathrm{DM}+\left(F_{1,18}=5.3, \mathrm{p}=0.03\right.$, Fig. $\left.2 \mathrm{~b}\right)$. H. diversicolor abundance was highest in the patch DJ, independent of the addition of the cockles $\left(F_{2,18}=6.2, \mathrm{p}=0.01\right.$; Fig. 2b). Its biomass did not differ significantly among patches, although it was larger in DM+ (Fig. 2c). The other species did not vary because of the cockle addition, but the density of Hydrobia ulvae was the lowest in DM (Fig. 2d). Heteromastus filiformis was more abundant in $\mathrm{C}$ than in $\mathrm{DM}$, and absent in $\mathrm{DJ}\left(F_{2,18}=\right.$ 68.3, p < 0.001; Fig. 2e). The large bivalves Scrobicularia plana (>20 mm), C. edule $(>13 \mathrm{~mm})$ and $M$. balth-

Fig. 1. (a) Non-metric multi-dimensional scaling ordination (nMDS) based on the Bray-Curtis dissimilarity. Distance between points is proportional to differences in macrofauna assemblages among replicate plots. (b) Mean (+SE) total number of individuals, biomass and number of species (diversity) for each assemblage without (-) and with (+) the transplanted cockles Cerastoderma edule in natural sediment $(\mathrm{C})$, sediment which had recolonised for 7 mo (DM) and sediment which had recolonised for 4 mo (DJ)
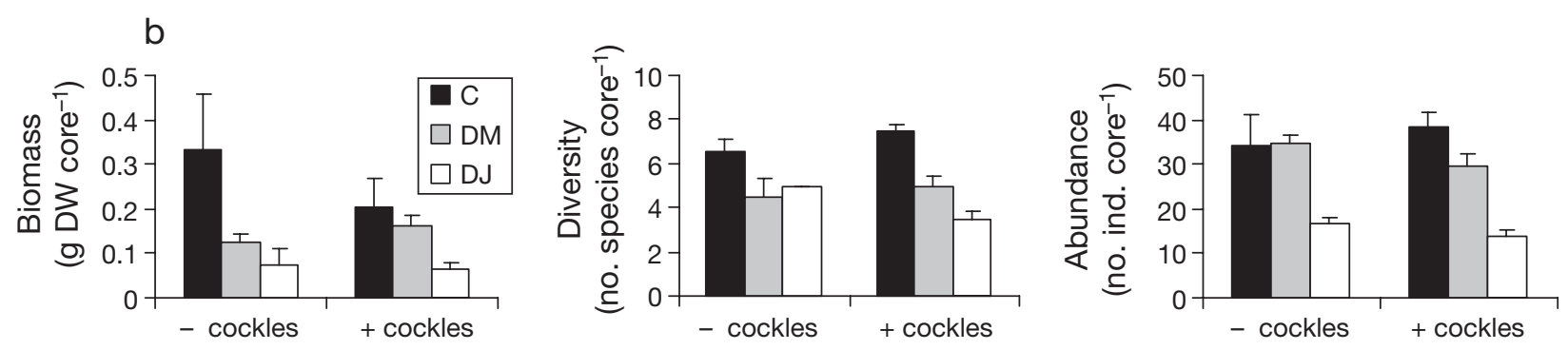

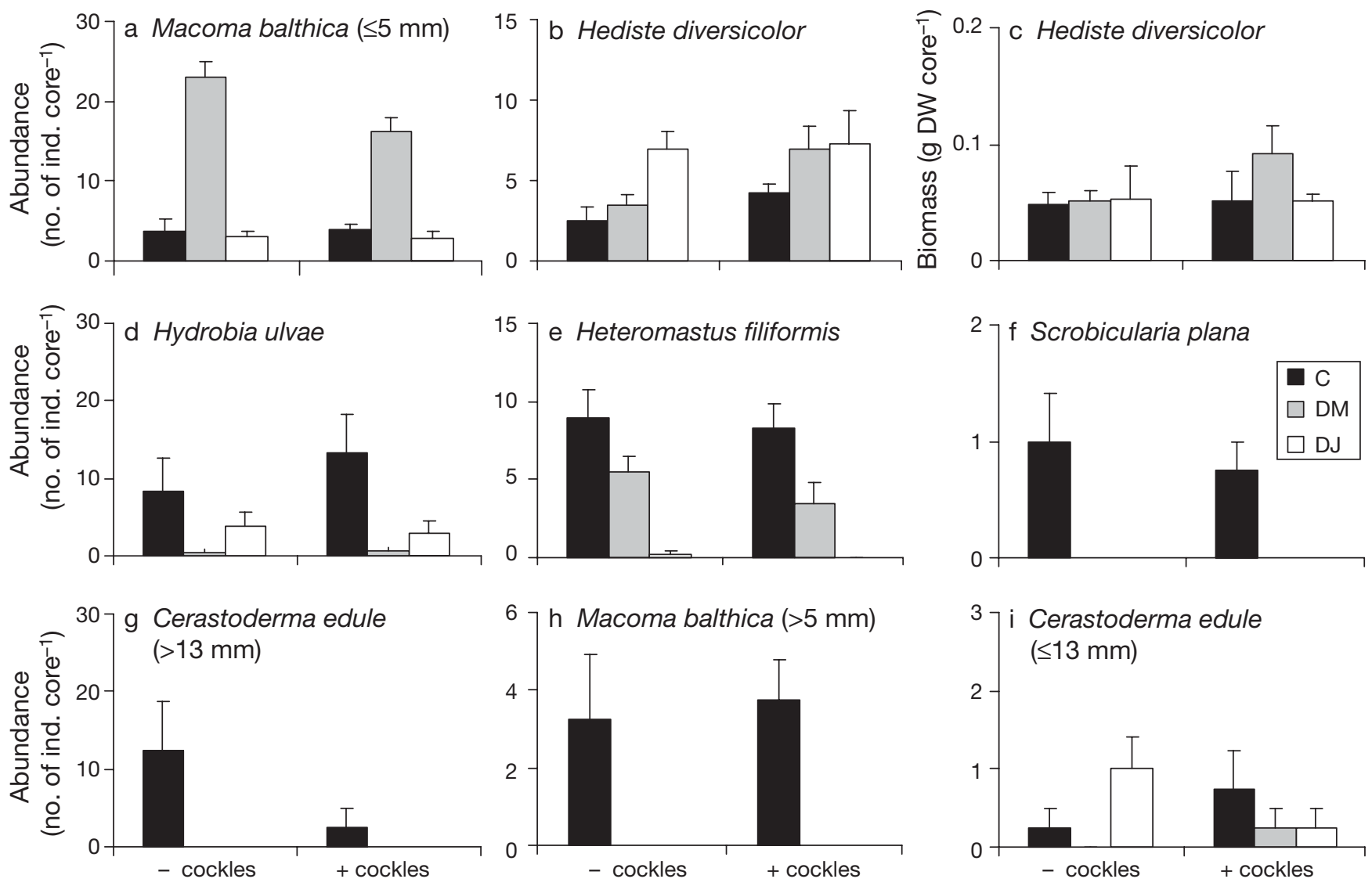

Fig. 2. (a,b,d-i) Mean abundance and (c) biomass (+SE) (n = 4 plots) of the 6 species dominating the assemblages without $(-)$ and with (+) the transplanted cockles Cerastoderma edule in natural sediment (C), sediment which had recolonised for 7 mo (DM) and sediment which had recolonised for 4 mo (DJ)

ica (>5 mm) were only found in C (Fig. 2e-h). Juveniles of $C$. edule $(\leq 13 \mathrm{~mm})$ were also observed in $\mathrm{DM}$ and DJ, but in low numbers (Fig. 2i).

\section{$\mathrm{NH}_{4}{ }^{+}$and $\mathrm{NO}_{3}{ }^{-}$flux}

Ammonium $\left(\mathrm{NH}_{4}^{+}\right)$was always released from the sediment to the water column, while nitrate $\left(\mathrm{NO}_{3}{ }^{-}\right)$was taken up from the overlying water. Following cockle addition, release of $\mathrm{NH}_{4}{ }^{+}$was enhanced 3 to 4 times from the sediment of DM $\left(F_{2,18}=5.9, \mathrm{p}=0.01\right.$; DM$<\mathrm{DM}+)$. Uptake of $\mathrm{NO}_{3}{ }^{-}$, instead, decreased in the other 2 patches $\left(F_{2,18}=4.1, \mathrm{p}=0.03 ; \mathrm{DJ}->\mathrm{DJ}+\right.$ and $\mathrm{C}->$ $\mathrm{C}+$ ), but not in DM- (Fig. 3). Fluxes of $\mathrm{NH}_{4}{ }^{+}$and $\mathrm{NO}_{3}{ }^{-}$ were not related to the biomass of the assemblage, but they co-varied with the abundances of Hediste diversicolor and Macoma balthica ( $\leq 5 \mathrm{~mm})$. Only in the treatment without cockles $(-)$, were correlation coefficients between nutrient flux and the abundance of $H$. diversicolor statistically significant $(\mathrm{r}=0.64, \mathrm{p}=0.01$ and $\mathrm{r}=$
0.82, $\mathrm{p}<0.001$, for $\mathrm{NH}_{4}{ }^{+}$and $\mathrm{NO}_{3}{ }^{-}$, respectively, $\mathrm{n}=12$ ). The correlations between the fluxes and the density of $M$. balthica $(\leq 5 \mathrm{~mm})$ was, instead, significant only in the plots with cockles added $(\mathrm{r}=-0.74, \mathrm{p}=0.003$ and $\mathrm{r}=$ $0.52, \mathrm{p}=0.04, \mathrm{n}=12$ for $\mathrm{NH}_{4}{ }^{+}$and $\mathrm{NO}_{3}{ }^{-}$, respectively). Changes in $\mathrm{NO}_{3}{ }^{-}$uptake due to cockles were high in DJ and $\mathrm{C}$ ( 7 and $6 \mu \mathrm{mol} \mathrm{d}{ }^{-1}$ ind. $^{-1}$, respectively), but the effect was limited in DM $\left(2 \mu \mathrm{mol} \mathrm{d} \mathrm{d}^{-1}\right.$ ind $\left.^{-1}\right)$.

\section{Oxygen and $\mathrm{CO}_{2}$ flux}

$\mathrm{O}_{2}$ uptake increased significantly in all assemblages when cockles were added $\left(F_{1,18}=21.9, \mathrm{p}<0.001\right)$. The release of $\mathrm{CO}_{2}$ to the water column was generally higher in the plots with added cockles than in those without. There was, however, a lot of variation among replicates $(\mathrm{SE}=9.4)$ and no significant differences $\left(F_{1,2}=6.2, \mathrm{p}=\right.$ $0.10 ;$ Fig. 4). There were also no significant differences in the respiration quotient $\left(\mathrm{RQ}=\mathrm{CO}_{2} / \mathrm{O}_{2}\right.$ flux), with values of $1.5 \pm 0.1($ mean $\pm \mathrm{SE}, \mathrm{n}=24)$. 

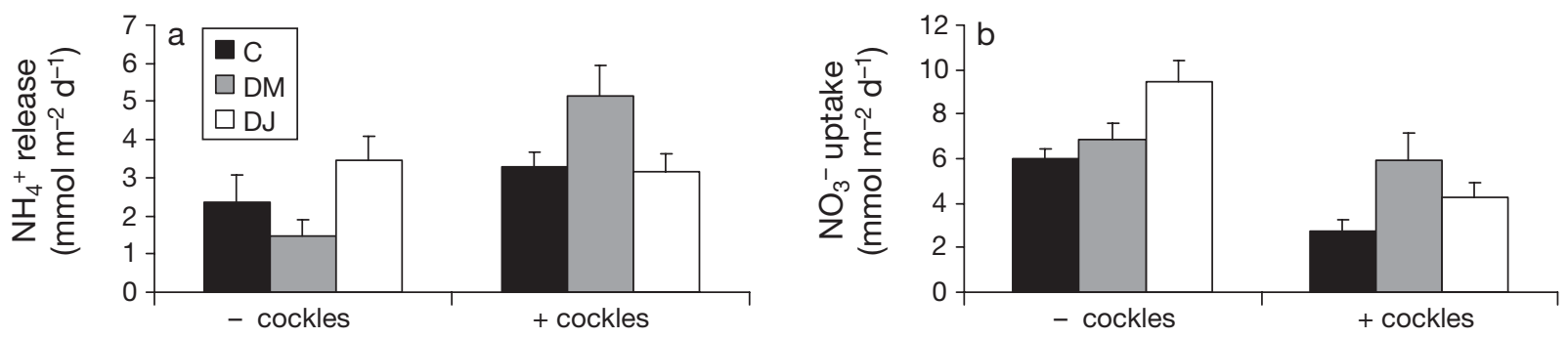

Fig. 3. Mean (+SE) (n = 4 plots) (a) $\mathrm{NH}_{4}{ }^{+}$release and (b) $\mathrm{NO}_{3}{ }^{-}$uptake without $(-)$and with (+) the transplanted cockles Cerastoderma edule in natural sediment $(\mathrm{C})$, sediment which had recolonised for 7 mo (DM) and sediment which had recolonised for 4 mo (DJ)
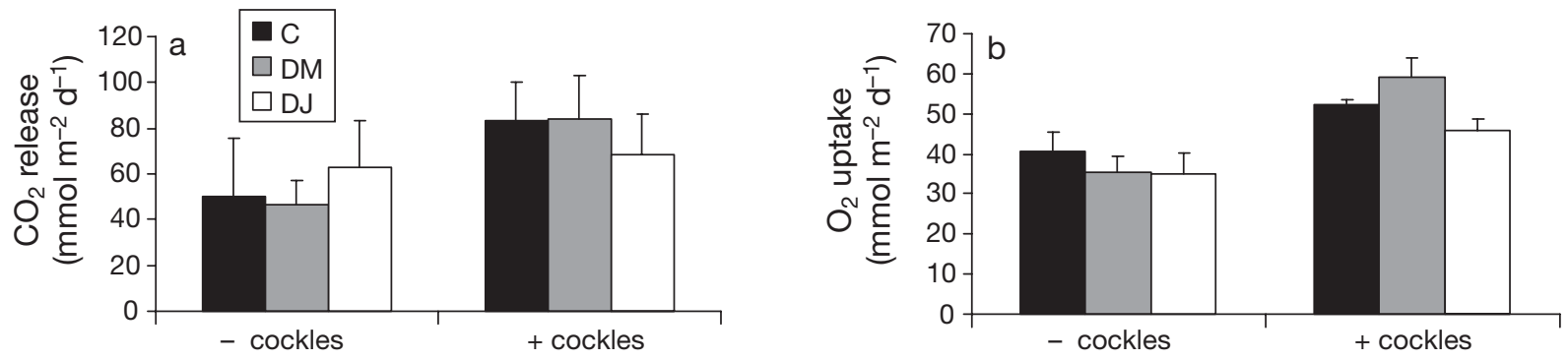

Fig. 4. Mean $(+\mathrm{SE})\left(\mathrm{n}=4\right.$ plots) (a) $\mathrm{CO}_{2}$ release and (b) $\mathrm{O}_{2}$ uptake, without $(-)$ and with $(+)$ the transplanted cockles Cerastoderma edule in natural sediment (C), sediment which had recolonised for 7 mo (DM) and sediment which had recolonised for 4 mo (DJ)

Uptake of $\mathrm{O}_{2}$ increased with increasing biomass $(\mathrm{r}=$ $0.59, \mathrm{p}=0.02, \mathrm{n}=12$ ) in the undisturbed sediment $(-)$. The significant value was due to $2 \mathrm{C}$ - replicates, one characterized by the largest biomass and abundance of cockles ( $0.37 \mathrm{~g} \mathrm{DW}$ core ${ }^{-1}$ and 6 ind.), the other by the largest biomass of bivalves (Cerastoderma edule, Scrobicularia plana and adult Macoma balthica; 0.17, 0.1 and $0.1 \mathrm{~g} \mathrm{DW}$ core $^{-1}$, respectively). Both replicates had an oxygen uptake similar to those measured in $\mathrm{C}+$ (52.2 and $41.6 \mathrm{mmol} \mathrm{d}^{-1} \mathrm{~m}^{-2}$ ). When these 2 cores were removed from the analyses, values dropped considerably $(\mathrm{r}=0.33, \mathrm{p}=0.18, \mathrm{n}=10)$.

Pearson correlation coefficients calculated for the dominant species in the assemblage showed that the flux of oxygen significantly varied with the abundance of Heteromastus filiformis in the undisturbed (-) treatments ( $\mathrm{r}=0.55, \mathrm{p}=0.05, \mathrm{n}=8)$. When cockles were added, however, r-values dropped considerably and they were not significant $(\mathrm{r}=-0.29, \mathrm{p}=0.24, \mathrm{n}=8$ ). Macoma balthica showed an opposite trend, with significant values following the addition of the cockles. Values of $r$ were $-0.20(p=0.27)$ and $0.85(p<0.001)$ in the undisturbed and transplanted plots, respectively.

The estimates for the respiration rate due to the addition of cockles, calculated using Eq. (1), showed that the uptake of $\mathrm{O}_{2}$ was only slightly higher in DM compared to $C$ and DJ $\left(16,20\right.$ and $28 \mu \mathrm{mol} \mathrm{d}^{-1}$ ind. $^{-1}$ in DJ, $\mathrm{C}$ and DM, respectively).

\section{Sediment porewater concentrations}

The variability of porewater $\mathrm{CO}_{2}$ concentrations was very low among assemblages, and the cockles only significantly decreased the concentration in the top $\mathrm{cm}$ $\left(3.70 \pm 0.04\right.$ and $3.54 \pm 0.05 \mu \mathrm{mol} \mathrm{l} \mathrm{l}^{-1}$ in - and + treatments, respectively; $\left.F_{1,18}=4.95, \mathrm{p}=0.04\right)$. The concentrations of $\mathrm{NH}_{4}{ }^{+}$and $\mathrm{NO}_{3}{ }^{-}$were unaffected by the presence of cockles, but the $\mathrm{NH}_{4}$ concentration differed among patches in the 2 to 4 and 4 to 6 depth horizons $\left(F_{2,18}=3.97, \mathrm{p}=0.05\right.$ and; $F_{2,18}=11.13, \mathrm{p}=0.003$, respectively). The lowest concentration of $\mathrm{NH}_{4}$ was observed in DM at 2 to $4 \mathrm{~cm}$ depth (DM < C = DJ: $96.0 \pm$ $9.2<128.4 \pm 10.4=133.9 \pm 13.5 \mu \mathrm{mol} \mathrm{l}^{-1}$ ) while values were similar to $C$ and lower than DJ in the 4 to $6 \mathrm{~cm}$ profile (Student-Newman-Keuls test, SNK: DM = C < DJ; $126.1=116.5 \pm 6.9<204.5 \pm 23.7 \mu \mathrm{mol} \mathrm{l} \mathrm{l}^{-1}$ ). The changes in these response variables were not correlated to any of the individual taxa or to the total biomass.

\section{DISCUSSION}

The functional response of ecosystems to species gain or loss is often variable according to the habitat characteristics, disturbance regime and community composition (Cardinale et al. 2000, Wardle \& Zackris- 
son 2005). In the present study, changes in biogeochemistry due to the gain of the suspension-feeder Cerastoderma edule were evaluated in patches of sediment with distinct macrofauna composition due to partial recovery from severe anoxia. The exchange of inorganic nitrogen at the sediment-water interface, indeed, varied according to the characteristics of the patches. Only at the late stage of recovery (DM) did the cockles cause a considerable increase in the release of ammonium (on average 3 to 4 times), while nitrate uptake remained stable. The response to cockle addition was similar in the early recovery stages and in the undisturbed patches (DJ and C).

When disturbance and habitat heterogeneity alter behavior and relative dominance of some species, ecosystem functions change because these species are functionally relevant or because they modify the functional traits and population dynamics of other key taxa (Cardinale \& Palmer 2002, Biles et al. 2003). Potentially, suspension-feeders are important for the biogeochemistry at the sediment-water interface because they modify water flow and nutrient mineralization. However, they can also alter the density and behavior of other macrofauna and microalgae which significantly contribute to carbon and nutrient recycling (Alpine \& Cloern 1992, Herman et al. 1999, Norkko et al. 2006, Thrush et al. 2006). In artificial assemblages, cockles have been found responsible for small changes in the ammonium flux, and they seldom show complementarity (sensu Petchey 2003) or interfere with the function of other species, including bioirrigation by Hediste diversicolor (Pelegri \& Blackburn 1995, Emmerson et al. 2001, Mermillod-Blondin et al. 2005, Ieno et al. 2006). Only when cockles are mixed with other suspension-feeders (e.g. Mytilus edulis) and the deposit-feeder Corophium volutator can there occasionally be complementary effects on ammonium flux (Emmerson et al. 2001).

Synthetic assemblage experiments evaluate the functional response of ecosystems to species composition over the short term and measure the complementarity (e.g. facilitation and niche-differentiation) of the different species in the assemblage, while reducing the effects of other ecological interactions considerably (Petchey 2003). Under natural conditions, the effects of macrofauna on biogeochemistry are not only directly linked to animal functional traits, but can also result from species interactions, habitat characteristics (Waldbusser \& Marinelli 2006) and species density (Marinelli \& Williams 2003). Functional response to the gain of a species can thus be more variable under natural than under laboratory conditions. In streams, for example, disturbance that maintains low dominance of suspension-feeders modifies benthic respiration and particulate organic matter recycling, because low dominance facilitates uptake of food within the suspension-feeder assemblage (e.g. increases complementarity) and promotes primary producer activity (Cardinale \& Palmer 2002). Removal of large filterfeeders from intertidal sediment, on the other hand, causes small decreases in the ammonium fluxes under dark conditions. However, it changes the direction of the nitrate flux (e.g. from release to uptake by the sediment) and enhances the densities of small suspensionfeeders and of the sediment dweller Heteromastus filiformis (Thrush et al. 2006). In our study, all 3 patches of sediment had relatively homogeneous microbial communities and sediment texture but differed in the number of functional groups of macrofauna, with functionality here defined primarily as feeding behavior and bioturbation activity (Pearson 2001). Cockles altered densities of some macrofauna species whose function could be important for ammonium fluxes.

Large suspension-feeders only occurred in natural sediments, and the head-down dweller Heteromastus filiformis appeared in DM and C. The species dominant in all the 3 patches were bioturbators, which feed on the sediment surface. In particular, newly recruited Macoma balthica $(\leq 5 \mathrm{~mm})$ feed primarily on microphytobenthos (Rossi et al. 2004) and Hediste diversicolor feed on detritus and occasionally on other small infauna. Following the addition of cockles, resident suspension-feeders were replaced, probably because of interference competition (Wilson 1990), and $H$. diversicolor reached the highest abundance in DM, comparable to DJ. In contrast, in DM newly recruited $M$. balthica were inhibited, probably by the feeding habit or micro-scale movements of cockles (Jensen \& Jensen 1985, Andre \& Rosenberg 1991, Flach 1996).

Sediment-water nutrient fluxes are governed by the balance of complex biogeochemical reactions and transport processes, which, in turn, are affected by animal excretion, microphytobenthos grazing, deposit feeding and bacterial stimulation by bioturbation and bioirrigation (Meysman et al. 2006). Although ammonium is also released by the animals themselves, this contribution is negligible compared to the microbial contributions; therefore, the measured fluxes represent effects of the fauna on sediment and microbes (Raffaelli et al. 2003). Furthermore, in the present study, fluxes were measured in the dark to exclude any effect due to microphytobenthos. The irrigation activity of Hediste diversicolor can play a key role in transporting ammonium from the sediment towards the overlying waters, since it flushes pore water in the top 10 to $15 \mathrm{~cm}$. Effects on nutrient regeneration are density-dependent for $H$. diversicolor (Ieno et al. 2006), and the enhanced density, mainly in DM, might in large part explain the increased ammonium 
flux towards the overlying water. It is worth noting that density rather than biomass was correlated to ecosystem function, which highlights the importance of considering density-dependent processes and not only those related to the biomass when dealing with measures of ecosystem functions. Nevertheless, if the effects of cockles were mediated by the density of $H$. diversicolor only, we would expect the release of ammonium to co-vary with the patterns of distribution of $H$. diversicolor. Therefore, patterns should be comparable between DM+ and DJ+, in which the abundance of $H$. diversicolor was similar (Fig. 2b). Density effects of adult Macoma balthica (shell length $>10 \mathrm{~mm}$ ) on ammonium fluxes are due to bioturbation and feeding. Patterns are not linear and the highest ammonium flux occurred at intermediate density treatments (Marinelli \& Williams 2003). In the present study, the correlation of newly recruited M. balthica density with the ammonium flux was observed only when density was reduced by the addition of cockles, which suggested this was a further mechanism to explain the observed changes in the ammonium flux. However, we should take into account that newly recruited $M$. balthica are less effective as bioturbators than their co-specific adults, and the magnitude of changes in density due to the cockle addition was probably not sufficient to justify the observed differences in the fluxes. Head-down, deep-dwelling maldanids, whose function can be comparable to that of Heteromastus filiformis (Pearson 2001), can regulate the flux of oxygen and render it available for nitrification of ammonium to nitrate (Waldbusser et al. 2004). The relationships between density of $H$. filiformis and oxygen consumption suggested an additional contribution of this species to the resulting ammonium flux.

It is also worth noting that the pattern of response of benthic respiration attributed to the addition of cockles was different from that of inorganic nitrogen flux. Benthic respiration, indeed, increased to a similar degree in all 3 patches and the values of respiration rates due to the cockles (16 to $28 \mu \mathrm{mol} \mathrm{d}{ }^{-1}$ ind. ${ }^{-1}$ ) were close to known values of cockle-specific respiration rates at $10^{\circ} \mathrm{C}$ (between 30 and $40 \mu \mathrm{mol} \mathrm{d}{ }^{-1}$ ind. $^{-1}$, Newell \& Bayne 1980). This suggests that the major effect of cockles on oxygen flux was related to their specific respiration rate, while other complex interactions seemed less important. Furthermore, the effect of cockles on the respiration rate appears to be related to their biomass. Not only did the respiration rates increase at a similar level in all patches, they were also comparable to rates in the natural sediment with similar cockle biomass. The effect of biomass on oxygen flux in a Scottish estuary was driven by the presence of the largest species found (Nepthys hombergi), which had a dis- proportionately large effect on oxygen flux, to the extent that it was proposed as a critical species for oxygen flux (Bolam et al. 2002). Likewise, in the present study, Cerastoderma edule added considerable biomass to the total biomass of resident fauna and, in turn, exerted a major influence on respiration rate, which makes this species also eligible as a critical species for ecosystem functioning, at least under certain conditions of biomass.

In summary, complex processes, rather than merely species function, modified the magnitude and direction of effects of increased Cerastoderma edule abundance on sediment biogeochemistry. The present experiment did not disentangle effects due to species interaction from other processes related to recolonisation patterns or spatial variability among patches. Nevertheless, the well-known role of macrofauna in nutrient regeneration, the effects of cockles on faunal abundances, and the correlation patterns observed indicated that the differences in the functional response to cockle addition were mediated by the resident fauna composition. This raises important considerations for further research on the relationships between biodiversity and ecosystem functions. First, functional response can be density-dependent and considering species interaction strength becomes fundamental. Second, it is worth noting that complex and non-monotonic functional response to species gain occurred at small scales, within a habitat. Many habitats, including marine sediments, are a mosaic of patches of distinct characteristics, often at different stages of recovery from natural disturbance. If functional response to diversity changes accordingly, it is necessary to consider scales of variability in populations and assemblages to predict the effects of biodiversity on the functions of an ecosystem. Researchers should, thus, put more effort into delineating the range of ecological conditions under which species gains or losses have monotonic relationships with ecosystem functions.

Acknowledgements. We thank M. Vos for his critical and helpful review of the manuscript and 3 anonymous referees for their thoughtful suggestions. We are also grateful to the people who helped in the field, in particular to C. van Colen, F. Montserrat, M. Ponti and T. Ysebaert. J. Sinke helped with the chemical analyses. This research is part of a large study done by the University of Gent, in collaboration with the CEME. This study was supported by the Netherlands Organisation of Scientific Research (NWO) (PIONIER and VENI projects). The authors acknowledge the support of the MarBEF Network of Excellence 'Marine Biodiversity and Ecosystem Functioning', which is funded by the Sustainable Development, Global Change and Ecosystems Programme of the European Community's Sixth Framework Programme (contract no. GOCE-CT-2003-505446). This is publication number 4142 of the Netherlands Institute of Ecology (NIOO-KNAW) and contribution number 07056 to MarBEF. 


\section{LITERATURE CITED}

Alpine AE, Cloern JE (1992) Trophic interactions and direct physical effects control phytoplankton biomass and production in an estuary. Limnol Oceanogr 37:946-955

Anderson MJ (2001) A new method for non-parametric multivariate analysis of variance. Austral Ecol 26:32-46

Andre C, Rosenberg R (1991) Adult-larval interactions in the suspension-feeding bivalves Cerastoderma edule and Mya arenaria. Mar Ecol Prog Ser 71:227-234

Biles CL, Solan M, Isaksson I, Paterson DM, Emes C, Raffaelli DG (2003) Flow modifies the effect of biodiversity on ecosystem functioning: an in situ study of estuarine sediments. J Exp Mar Biol Ecol 285-286:165-177

Bolam SG, Fernandes TF, Huxham M (2002) Diversity, biomass, and ecosystem processes in the marine benthos. Ecol Monogr 72:599-615

Boschker HTS, Middelburg JJ (2002) Stable isotopes and biomarkers in microbial ecology. FEMS Microbiol Ecol 40:85-95

Bruno JF, O'Connor MI (2005) Cascading effects of predator diversity and omnivory in a marine food web. Ecol Lett 8:1048-1056

Cardinale BJ, Palmer MA (2002) Disturbance moderates biodiversity-ecosystem function relationships: experimental evidence from caddisflies in stream mesocosms. Ecology 83:1915-1927

Cardinale BJ, Nelson K, Palmer MA (2000) Linking species diversity to the functioning of ecosystems: on the importance of environmental context. Oikos 91:175-183

Chapin FS III, Zavaleta ES, Eviner VT, Naylor RL and others (2000) Consequences of changing biodiversity. Nature 405:234-242

Clarke KR, Gorley N (2001) Primer v5: user manual/tutorial. PRIMER-E, Plymouth

Costanza R, d'Arge R, de Groot R, Farber S and others (1997) The value of the world's ecosystem services and natural capital. Nature 387:253-260

Diaz S, Symstad AJ, Chapin FS, Wardle DA, Huenneke LF (2003) Functional diversity revealed by removal experiments. Trends Ecol Evol 18:140-146

Dufrene M, Legendre P (1997) Species assemblages and indicator species: the need for a flexible asymmetrical approach. Ecol Monogr 67:345-366

Emmerson MC, Solan M, Emes C, Paterson DM, Raffaelli D (2001) Consistent patterns and the idiosyncratic effects of biodiversity in marine ecosystems. Nature 411:73-77

Flach EC (1996) The influence of the cockle, Cerastoderma edule, on the macrozoobenthic community of tidal flats in the Wadden Sea. PSZN I: Mar Ecol 17:87-98

Hall PO, Aller RC (1992) Rapid, small-volume, flow-injection analysis for sigma- $\mathrm{CO}_{2}$ and $\mathrm{NH}_{4}{ }^{+}$in marine and freshwaters. Limnol Oceanogr 37:1113-1119

> Heip CHR (1998) Marine biodiversity. Biofutur 179:12-17

Herman PMJ, Middelburg JJ, Van de Koppel J, Heip CHR (1999) Ecology of estuarine macrobenthos. Adv Ecol Res 29:195-240

Hooper DU, Chapin FS, Ewel JJ, Hector A and others (2005) Effects of biodiversity on ecosystem functioning: a consensus of current knowledge. Ecol Monogr 75:3-35

$>$ Hurlbert SH (1984) Pseudoreplication and the design of ecological field experiments. Ecol Monogr 54:187-211

Ieno EN, Solan M, Batty P, Pierce GJ (2006) How biodiversity affects ecosystem functioning: roles of infaunal species richness, identity and density in the marine benthos. Mar Ecol Prog Ser 311:263-271

Jensen KT, Jensen JN (1985) The importance of some epi- benthic predators on the density of juvenile benthic macrofauna in the Danish Wadden sea. J Exp Mar Biol Ecol 89:157-174

Kamermans P (1994) Similarity in food source and timing of feeding in deposit- and suspension-feeding bivalves. Mar Ecol Prog Ser 104:63-75

Loreau M, Naeem S, Inchausti P (2002) Biodiversity and ecosystem functioning. Synthesis and perspectives. Oxford University Press, New York

Marinelli RL, Williams TJ (2003) Evidence for densitydependent effects of infauna on sediment biogeochemistry and benthic-pelagic coupling in nearshore systems. Estuar Coast Shelf Sci 57:179-192

Mermillod-Blondin F, Francois-Carcaillet F, Rosenberg R (2005) Biodiversity of benthic invertebrates and organic matter processing in shallow marine sediments: an experimental study. J Exp Mar Biol Ecol 315:187-209

Meysman FJR, Middelburg JJ, Heip CHR (2006) Bioturbation: a fresh look at Darwin's last idea. Trends Ecol Evol 21:688-695

Naeem S, Thompson LJ, Lawler SP, Lawton JH, Woodfin RM (1994) Declining biodiversity can alter the performance of ecosystems. Nature 368:734-737

Naeem S, Loreau M, Inchausti P (2002) Biodiversity and ecosystem functioning: the emergence of a synthetic ecological framework In: Loreau M, Naeem S, Inchausti P (eds) Biodiversity and ecosystem functioning. Synthesis and perspectives. Oxford University Press, New York, p 3-11

Newell RIE, Bayne BL (1980) Seasonal changes in the physiology, reproductive condition and carbohydrate content of the cockle Cardium (= Cerastoderma) edule (Bivalvia: Cardiidae). Mar Biol 56:11-19

Norkko A, Hewitt JE, Thrush SF, Funnell GA (2006) Conditional outcomes of facilitation by a habitat-modifying subtidal bivalve. Ecology 87:226-234

Nowlin WH, Drenner RW (2000) Context-dependent effects of bluegill in experimental mesocosm communities. Oecologia 122:421-426

Pearson TH (2001) Functional group ecology in soft-sediment marine benthos: the role of bioturbation. Oceanogr Mar Biol Annu Rev 39:233-267

Pelegri SP, Blackburn TH (1995) Effect of bioturbation by Nereis sp., Mya arenaria and Cerastoderma sp. on nitrification and denitrification in estuarine sediments. Ophelia 42:289-299

$>$ Petchey OL (2003) Integrating methods that investigate how complementarity influences ecosystem functioning. Oikos 101:323-330

Raffaelli D, Emmerson M, Solan M, Biles C, Paterson D (2003) Biodiversity and ecosystem processes in shallow coastal waters: an experimental approach. J Sea Res 49:133-141

Rossi F, Herman PMJ, Middelburg JJ (2004) Interspecific and intraspecific variation of $\delta^{13} \mathrm{C}$ and $\delta^{15} \mathrm{~N}$ in depositand suspension-feeding bivalves (Macoma balthica and Cerastoderma edule): evidence of ontogenetic changes in feeding mode of Macoma balthica. Limnol Oceanogr 49:408-414

Rossi F, Forster RM, Montserrat F, Ponti M, Terlizzi A, Ysebaert T, Middelburg JJ (2007) Human trampling as shortterm disturbance on intertidal mudflats: effects on macrofauna biodiversity and population dynamics of bivalves. Mar Biol 151:2077-2090

Schmid B, Hector A (2004) The value of biodiversity experiments. Basic Appl Ecol 5:535-542

Solan M, Cardinale BJ, Downing AL, Engelhardt KAM, Ruesink JL, Srivastava DS (2004) Extinction and eco- 
system function in the marine benthos. Science 306: $1177-1180$

Stachowicz JJ, Whitlatch RB, Osman RW (1999) Species diversity and invasion resistance in a marine ecosystem. Science 286:1577-1579

Thrush SF, Hewitt JE, Gibbs M, Lundquist C, Norkko A (2006) Functional role of large organisms in intertidal communities: community effects and ecosystem function. Ecosystems (N Y, Print) 9:1029-1040

Tilman D, Knops J, Wedin D, Reich P, Ritchie M, Siemann E (1997) The influence of functional diversity and composition on ecosystem processes. Science 277:1300-1302

Editorial responsibility: Lisa Levin,

La Jolla, California, USA
Waldbusser GG, Marinelli RL (2006) Macrofaunal modification of porewater advection: role of species function, species interaction, and kinetics. Mar Ecol Prog Ser 311:217-231

Waldbusser GG, Marinelli RL, Whitlatch RB, Visscher PT (2004) The effects of infaunal biodiversity on biogeochemistry of coastal marine sediments. Limnol Oceanogr 49:1482-1492

Wardle DA, Zackrisson O (2005) Effects of species and functional group loss on island ecosystem properties. Nature 435:806-810

Wilson WH (1990) Competition and predation in marine softsediment communities. Annu Rev Ecol Syst 21:221-241

Submitted: February 2, 2007; Accepted: August 17, 2007 Proofs received from author(s): January 18, 2008 